
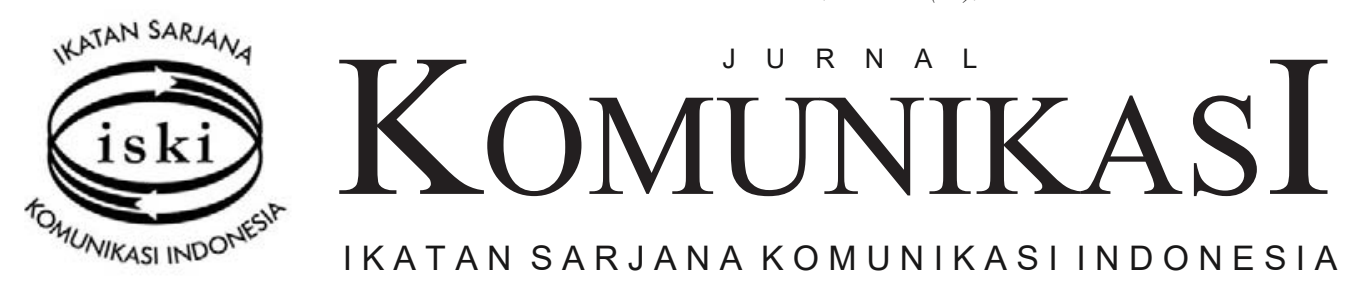

E-ISSN: 2503-0795

P-ISSN: 2548-8740

IKATANSARJANAKOMUNIKASI INDONESIA

\title{
Developing Social Solidarity through Digital Media
}

\author{
http://dx.doi.org/10.25008/jkiski.v3i1.144 \\ Eni Maryani \\ Universitas Padjadjaran, Bandung, 45363 - Indonesia \\ eni.maryani@unpad.ac.id
}

\begin{abstract}
This research raises the issue on digital media by activists in an effort to gain wider public involvement towards the social transformation process based on social solidarity. The development of digital media broadens the space to raise a range of marginal issues in public spaces controlled by predominant social groups. Digital media provides elite and mainstream media an opportunity for counter public spheres to dominate issues. Data collection is conducted through interviews and observation. There are both opportunities and challenges in utilizing digital media to build social solidarity. Characteristics of digital media allow a faster reach of a wider and diverse audience as well as generate an increasingly fierce global competition. Technologically, digital media only gives a very short opportunity to hold the audience' attention. Therefore, communication among humans is still needed to strengthen and build public trust. The occurrence of a communication has significant effect when online media are parallel with activities and issues that are offline, demands both forms of communication to be used simultaneously.
\end{abstract}

Key words: Social solidarity, Digital media, Counter public sphere

\begin{abstract}
Abstrak
Penelitian ini mengangkat penggunaan media digital oleh para aktivis untuk memperluas keterlibatan publik dalam proses transformasi sosial berbasis solidaritas sosial. Perkembangan media digital memperluas ruang untuk mengangkat beragam isu-isu marjinal dalam ruang publik yang dikendalikan kelompok dominan. Media digital memberi peluang terjadinya counter public sphere terhadap dominasi isu oleh kelompok elit dan media mainstream. Pengumpulan data dilakukan melalui wawancara dan observasi. Terdapat peluang sekaligus tantangan dalam memanfaatkan media digital dalam membangun solidaritas sosial. Karakteristik media digital memungkinkan tercapainya khalayak lebih luas, beragam dan lebih cepat sekaligus juga menghasilkan persaingan global yang semakin ketat. Secara teknologi media digital hanya memberi kesempatan yang sangat singkat untuk menahan perhatian khalayak. Oleh kaarena itu komunikasi antar manusia tetap dibutuhkan untuk memperkuat dan membangun kepercayaan khalayak. Terjadinya komunikasi melalui media on line yang paralel dengan aktivitas dan isu yang bersifat off line menuntut kedua bentuk komunikasi tersebut digunakan secara bersamaan.
\end{abstract}

Kata Kunci: Solidaritas sosial, Media digital, Counter public sphere

Copyright @ 2017 Ikatan Sarjana Komunikasi Indonesia. All rights reserved 


\section{Introduction}

The dynamics that occur in society provide a variety of changes in various fields both social issues as well as solutions of the existing problems. Issues concerning violence on women is one of examples that develops since the existence of man. The 1998 reform is one important turning point in Indonesia's history. The change of political leadership after reigning over 30 years of power brought about new dynamics in the authority system in Indonesia.

The development of digital technology in communications opens many new spaces and widens the interaction opportunity among people. To date the growth of internet usage in Indonesia continues to increase, although it is undeniable that the increase is correlated to the availability of infrastructure in each respective regions and its people's economic ability. In reference to its development, the digital media is important in reaching the greater audience quickly. The effort in reaching the masses is not only needed by product producers to their customers but also important for various advocate institutions to handle their numerous issues. One of such institutions that considers the digital media as a strategic tool to achieve their means is an organization called the Indonesia untuk Kemanusiaan (IKa, Indonesia for Humanity). Referring to the type of institution, the work mechanism and the target of this institution is undeniable to use the media to reach the greater masses consisting of various backgrounds. Therefore one of IKa's activities is to develop social solidarity through the digital media. Indonesia untuk Kemanusiaan is a resource institution that develop empowerment to support applicable and sustainable change for humanity (http://indonesiauntuk kemanusiaan .org/november/2017).

In coherence with the aim of the institution, IKa gathers and manages resources and distributes them to the people. The resources they have gather, managed and distributed covering four types of resources -Funds, Knowledge, Network and Volunteers. These resources in the work of mechanism and advocate of IKs are called Catur Daya (Four Powers). Meanwhile several organizations and institutions involved in every work mechanism of IKa, whether as resource, managers or users of the resources are called Komunitas Pemberdaya (the Empowering Community).

This research reveals how IKa uses the digital media to develop social solidarity on a global level to deal with issues on violence towards women.

\section{Theoretical Framework}

As part of technology, the digital media has several main characteristics that underlie big changes in the communication system. According to Creeber and Martin four main characteristics of the new media are their capability in being Interactive, Hypertextual, Virtual/Simulated, and Networked (Creeber \& Martin, 2009).

In the digital media "Interactive" means the audience are assumed to no longer be passive but active in using the media. "Active", here, means that when the audience are able to "interact" with texts in the digital media, they are able to input data (be it text, pictures, photo, audio, etc.) into a media, that is when they are called "users" (active) and not just "viewers" or "readers" (passive), the audience choose how they will use the media (personal use type). Meanwhile "Hypertext" is a characteristic of the digital media which is simply to put it-- it is an electronic text refering to some other text/ database that can instantly be accessed by the users.

The characteristic of the digital media in the form of network technology that has new generation is always connected to the internet in almost all aspects of their life. This in turn, will cause significant changes in people's lifestyle, social relationships, culture etc. In the development of the digital media usage, new communities arise (virtual community) that is not limited or based on geographical location, but by new media forums, social media, etc. In other words, "virtual" in the digital media context may refer to a new form of communication in the digital media such as emoticons/stickers to convey "virtual emotions", or avatars to represent their selves.

Based on characteristics of the digital media several significant changes have been occurred. These important changes are: a) digital data become easier to store and share in various formats, b) digital data become easier to manipulate, either to add, delete, copy (duplicate, reproduce) and so on, c) digital data can be stored easier and more practical, 
d) digital data do not need physical space as analog data, and e) they can be accessed and retrieved easier and fast.

In reference to the digital media characteristic and its significant implication towards changes in the communication process thus the use of the digital media becomes a development and need for many groups in many fields and activities. The digital media becomes an alternative against mainstream public media space where the elite group or authority tends to cooperate. The power of the digital media as a social network is in line with Castells who placed the origin of social network as an information and technology revolution in the early 1070s. The key to this revolution, according to Castells, is the invention of the microprocessor, which make it possible for the birth of the personal computer and the distribution of the computer network beyond military and scientific use (Castell, 1996).

Virtual communication is categorized as a group consisting of people using electronic device as a primary form of communication among them (Dennis, Pootheri, \& Natarajan, 1988 -tlg cari original quote). Virtual network community groups also build solidarity as conveyed by Riding and Geffen, " "The feeling of being together and being a member of a group of friends comes with the notions of being part of a group, spending time together, companionship, socializing, and networking" (Ridings, C. M. and Gefen, D, 2004)

The power of the digital media as a network media also develops into a new public space facilitated by various social media. Contrary to public space in the mainstream media which is controlled by a selected few, the developing public space in the digital media, specifically social media provides access to the greater audience, in fact geographically unlimited. The social media is one source that can counter the dominance of public space. According to Fenton and Downey this is due to the incompetence of traditional country's political parties in handling global issues that deteriorates day by day such as inequality and environmental issues. That is why they think there needs to be a new social movement to raise hope to support democracy, both locally as well as globally. Counter public sphere is necessary to counter the existence of increasingly privatized public space (Fenton \& Downey, 2014).

To conduct counter public sphere as mentioned by Fenton and Dewey, it is important to develop an alternative media to handle issues concerning public interests. The digital media has the potential to develop an alternative media in an effort to raise various public issues including issues that are advocated by activists for their social movements. They become the balance for issues that spread in the mainstream media. According to Poell and Dicjk the result of their research concludes that the social media platform as part of technology is capable of developing the mobilization process and communication activities. The social media is quite useful for activists in making report in terms of speed, range and in accessing a variety of resources for information. At the same time, activists are also challenged, as Poell and Dicjk stated, "The challenge for activists is to profit from the affordances of social platforms while simultaneously gaining public attention for the fundamental issues at stake in contemporary protests, and to continue building communities around these issues. If the recent resurgence of activism is to lead to real political change, it remains important not only to mobilize people, but also to raise their political awareness and to tie them into durable networks, which can press for change in the long run" (Poell dan Dicjk, 2014).

In relations to the mechanism of empowerment through the social media, Li explained that this process involves two factors, the individual and context. The empowerment of individuals also involves the process of empowering people interpersonally and their interactions which emphasizes on their effect contextually. The social media users that are potential to be empowered, most often act as opinion leaders online and they certainly know how to use the new media platform to maximize their influence on others. ( $\mathrm{Li}, 2016)$.

Aside from that, there needs to be a mechanism for empowering people that can help direct human relations among the professionals.

Based on the conceptual frame and theory exposed above, it is formulated that the digital media has the potential to accelerate the gathering process - processing it and distributing the information to develop social solidarity. The occurrence of issues 
about marginalization in the public sphere of mainstream media needs other media to represent it. The question is, what are the chances and obstacles in using the digital media as an alternative media and activism media to conduct the process of social transformation.

\section{Material and Methodology}

This research uses qualitative method to acquire holistic understanding towards the reality of this research (Mulyana, 2007). As a qualitative research that uses study cases, this research utilizes various sources of information to understand the case on hand. Thus generally in studies like this several data compilation techniques are used such as indepth-interviews, observation and literature study (Creswell, 2007).

IKa's fund raising staff as well as IKa's information communication staff and coordinator of violence against women staff's issue is the source for the in-depth-interview. Interviews are also conducted towards observers of Indonesia's digital media. Whereas observations are made on the content or materials on IKa's which advocates as a resource institution and the global.giving.fund website. Meanwhile to complete several secondary data, data collection were conducted in coherence with literature studies.

\section{Results and Discussion}

\section{IKa as Resource Institute}

IKa was created in 1995 under the name Yayasan Sosial Indonesia untuk Kemanusiaan (YSIK or Indonesian Social and Humanitarian Foundation) in Jakarta. The birth of YSIK was conceived during the repressive New Order regime. YSIK played a role as supporting efforts in building democracy, justice and human rights. In the midst of this repressive situation, YSIK began as a silent foundation who relied their livelihood on trust among networks that rooted in and throughout the archipelago then extended to various countries. In 2010 , in line with the great change which began right after the 1998 reform, a principal transformation also took place in YSIK. In keeping with the new open atmosphere of the reform era, the YSIK administration has built its self-sustainability and continuity as an institution of resources. YSIK also develops into a public institution that is more open and aims to be more recognized by the over-all community. Therefore in consistence with their objective YSIK has renamed themselves to Indonesia untuk Kemanusiaan (IKa) to make it easier for people to pronounce and remember IKa as a public institution that manages resources (http://indonesiauntuk kemanusiaan.org/tentangindonesia-untuk kemanusiaan/November/2017)

Ika's work mechanism involves fund raising from various sources, the government, donors, institutions or public, organizations or individuals. The ideal composition Ika hopes that the funds are equal parts among the public, donors and the government.

Meanwhile, when it comes to pooling knowledge, IKa gathers information concerning 4 issues that IKa focuses on violence towards women, cultural diversity, food sovereignty, and violation of human rights. Knowledge on these matters may be in the form of understanding these issues, or materials which help to increase the capacity of individuals or institutions in handling problems concerning these four matters mentioned. The information gathered, is managed and distributed by IKa through various media -printed or digital - and competent experts on these four issues are specialists theoretically as well as in practice.

The network is all forms of relations that are owned and facilitated by IKa in the entirety of its work mechanism, gathering the stage, managing as well as distribution of resources. The network continues to expand in accordance with the network of all the institutions or individuals that are part of IKa's network.

Through its network, IKa not only expands their work range and audience coverage but also builds its strength as a resource institution. At present, contextually, IKa's network is not only built locally but also internationally. As a member of the Perhimpunan Filantropi Indonesia (PFI), as a resource organization IKa is the one and only resource institution that is a member of international resource institutions such as urgent action aid,

\section{Increase Capacity through Digital Media}

IKa increases some efforts in fund raising for Pundi Perempuan through a variety of endeavors and 
activities by inviting and recruiting as many people as possible from various backgrounds of the members of empowerment community who are able to empower others. One of IKa's efforts was to get as many people as possible on a national level to be involved with handling violence towards women. This effort includes crowdfunding on an international level through GlobalGiving www.globalgiving.org/projects/pundiperempuan-.

To accept and attain room for interaction in the network provided by GlobalGiving, every organization must prove their capacity in building their donor network. For this purpose, IKa was given a limited time of two weeks, 11-30 September 2017 to gather funds at least reaching a minimum of 5000 US\$ from their donors. To reach that target they had to make some preparations, such as providing information - materials on Pundi Perempuan which describes the definition, area of distribution and ways to contribute both in English as well as Bahasa Indonesia organized by IKa's Fundraising Assistant as the Leader of this project financed by the assistant of information and communication. The content is discussed by the fundraising assistan, program manager, Ika volunteers. The content is then turned into a sharegraphic by Ika graphic designer. This sharegraphic functions as information about Ika for the community at large that may be used and publicized by various media and for further uses as well.

Before the project started, IKa's fundraising asisstant followed an online training (webinar) in GlobalGiving.org alongside the project leader and other due diligent around the world who will join the accelerator program for four days in September, a full hour for each day. This training will explain how to maintain and manage the project page in GlobalGiving by posting information, photos, see reports, dotation process, sending thank you emails to donators etc. The fundraising assistant as the project leader will fill requirements in the Pundi Perempuan page in the GlobalGiving website. The Information and Communication assistant of IKa will then make asocial media plan for the duration of the GlobalGiving project to publicize the project to the public. The entire preparation takes a little more than two weeks. During the fund raising process, the information and communication assistant will publicize the GlobalGiving sharegraphic through the social media via facebook, twitter, and instagram as well as whatsapp groups related to IKa and Pundi Perempuan.

To meet the challenge, IKa's staff has disseminated information about the fund gathering through GlobalGiving Fund to all associates and networks that are potential to donate. IKa prepared an account number for donator who do not have or are not inclined to use credit cards. The Project Leader sends emails thanking all donators after each donation. IKa's information and communication assistant update every new piece of information on the total number of donations received in a certain period of time and a thank you note to Friends of IKa (this is what IKa's community is called). It was tough in the beginning to find donations. In the last week the number of donations sky rocketed after the staff, board. Thus IKa network spreads the information to all their relations and contacts those who are potentials as donators and follow up on each lead. In the end IKa successfully achieved their target given by GlobalGiving and in fact the attained fund was more than expected totalling 7.753 USD.

\section{Digital Media as Challenge and Opportunity}

Based on IKa's success, in two weeks they raised $\$ 7500$ or no less than Rp. 104.000 .000 , so on September 2017 IKa was entitled to a homepage time in GlobalGiving. In turn Pundi Perempuan attained a rating of 27 out of 627 in GlobalGiving. Through its achievement, IKa will appear on the front page of GlobalGiving.org on April, 212018 with a new project. The appreciation given by GlobalGiving to IKa is also a challenge for them to create a short message in Globalgiving Fund that can attract readers. Practically one of the digital media practitioners reveals that through electronic media we only have 10-15 seconds to be able to attract and retain audiences, but based on the digital media time we only have 7-10 seconds. This means that in 7-10 seconds if the media content is not attractive to users then they will quickly move on to other sites.

As a member of GlobalGiving, IKa at any given time can make a donation for a project in GlobalGiving and access training online and their tools- to explain how to manage a project in 
GlobalGiving. This opportunity is also a challenge, because in the Global Giving Fund site, as a resource institution, IKa has many competitions, other contending resource institutions around the world and has relatively the same communication target to reach as many viewers as possible to be users or potential donors.

\section{Conclusion}

Based on the experience of Indonesia untuk Kemanusiaan, there are many lessons learned in using the digital media to develop social solidarity. In reference to the increasing phenomena, this research concludes: (1) The characteristics of digital media provides opportunities for acceleration in the process of searching, processing and distributing information. But technologically, the digital media simultaneously bring about the challenge to be able to attract quickly - within 7-10 seconds and retain the audience's attention to the content we are distributing; (2) The wide range of issues available online and in parallel with existing offline content has reciprocal and complementary ties. This means that if the existing content in online media is not in line with the information available in offline media then it is generally difficult to attract the attention of the audience; (3) Interpersonal communication has the power where digital media users still need to enable them to build and increase trust and share information. Through communication among humans, the information contained in digital media should be reflected or discussed.

Based on information elaborated in the research, there are several recommendations that may be taken into consideration in the process of social transformation: First, the use of digital media has advantages but also weaknesses. To overcome this, it requires another form of communication that does not use the media. Second, both the development of digital-based communications infrastructure that enables global communications to be facilitated, it should be followed by increased capacity of users in the production and management of digital media content. It is necessary to avoid communication gaps based on limited local or national content compared to the growing global content in the digital media

\section{References}

Castell, Manuel (1996). The Rise of Network Society, Blackwell Publishing Ltd, London

Creswell, John W, (2013), Qualitative Inquiry \& Research Design, Sage Publication.inc, Washington DC.

Creeber, Martin (2009). Digital Cultures: Understanding New Media. Open University Press.

Fenton, Natalie, dan Downey, John, (2014). Counter Public Spheres and Global Modernity, Javnost / The Public. November 2014 DOI: 10.1080/13183222.2003.11008819 · Source: OAI

http://indonesiauntukkemanusiaan.org/tentangindonesia-untuk-kemanusiaan/november/2017

Mulyana, Deddy \& Solatun, (2007), Metode penelitian komunikasi: contoh-contoh penelitian kualitatif dengan pendekatan praktis, Rosda Karya, Bandung. 